"A Theoretical and Empirical Analysis of the Decision to Locate on a University Research Park."

IEEE Transactions on Engineering Management, 2008, 55(1): 23-8. Co-authored with Albert N. Link and Donald S. Siegel.

Made available courtesy of Institute of Electrical and Electronics Engineers: http://www.ieee.org/

$* * *$ Reprinted with permission. No further reproduction is authorized without written permission from the Institute of Electrical and Electronics Engineers. This version of the document is not the version of record. Figures and/or pictures may be missing from this format of the document.***

\title{
A Theoretical and Empirical Analysis of the Decision to Locate on a University Research Park *
}

\author{
Dennis P. Leyden \\ Department of Economics \\ University of North Carolina at Greensboro \\ Greensboro, NC 27402 \\ leyden@uncg.edu \\ Albert N. Link ** \\ Department of Economics \\ University of North Carolina at Greensboro \\ Greensboro, NC 27402 \\ (336) 334-5146 \\ anlink@uncg.edu \\ Donald S. Siegel \\ Department of Economics \\ Rensselaer Polytechnic Institute \\ 3506 Russell Sage Laboratory \\ Troy, NY 12180-3590 \\ sieged@rpi.edu
}

* We gratefully acknowledge the capable computational assistance of Todd Crawford.

** Corresponding author. 


\title{
A Theoretical and Empirical Analysis of the Decision to Locate on a University Research Park*
}

\begin{abstract}
University research parks constitute a potentially important mechanism for university technology transfer and regional economic development. Unfortunately, there is little theoretical and empirical evidence on the firm-level choice decision to locate on such a facility. We fill this gap by outlining and testing a theoretical model of this selection process. Our empirical results suggest that firms locating on university research park are more research active and more diversified than observationally equivalent firms.
\end{abstract}

Keywords: Science Parks, R\&D, Productivity, University Technology Transfer JEL Codes: O32, O33, O38, L31 


\section{Introduction}

University research parks were established to stimulate to facilitate technology transfer and the creation, growth, and development of high technology firms. Universities support research parks in order to enhance their prestige, secure additional funding from the private sector, generate rental income, ensure that university research is more relevant to industry, and to provide job opportunities for students and post-docs. Government provides financial support for university research parks because they view such institutions as a mechanism for generating technological spillovers and employment growth

Unfortunately, there has been little theoretical or empirical analysis of the firmlevel choice decision to locate on such a facility. The purpose of this paper is to fill this gap. Specifically, we outline a theoretical model of this selection process, which we test using the population of public-traded firm who report positive R\&D expenditures.

The remainder of this article is organized as follows. In Section II, we provide background information on university research parks. Section III outlines the theoretical model. In Section IV, we present empirical results. The final section contains caveats, preliminary conclusions, and a brief discussion of the economic and managerial implications of our findings.

\section{Background Information on University Research Parks}

In recent decades, we have witnessed substantial growth in the number of university research parks across the globe. According to Link and Scott (2003) there are 81 active university research parks in the U.S. The U.K. Science Park Association (UKSPA) reports that there are 100 science parks in the U.K., most of which are based on or near U.K. universities. Phan, Siegel, and Wright (2005) identified over 200 science 
parks in Asia , including 111 in Japan alone. China has also been recently active in this arena.

In the U.S., the formation of university research parks increased rapidly in the early 1980s due in large part to the passage of the Bayh-Dole Act in 1980, the R\&E tax credit in 1981, and the National Cooperative Research Act of 1984. This growth pattern in formations is similar across regions of the United States. We also know that U.S. parks vary substantially in size. For example, Research Triangle Park in North Carolina currently has 45,000 employees working on 7,000 acres and Colorado Bioscience Park in Aurora currently has 50 employees on 147 acres. Of the population of 81 university research parks through 2002, 20 percent are focused exclusively on biotechnology and 17 percent are single focused on information technology. Of the 39 U.S. university research parks in the planning stage at the end of 2002, 90 percent are located at state universities; 40 percent plan to focus on biotechnology; 30 percent are located at Carnegie Extensive universities; and over 50 percent of the provosts at planned parks state that the major reason for starting the park was related to regional economic development.

Link and Scott (2006) report that U.S. science parks have changed the research environment at American universities. They conducted an extensive survey of university provosts to assess the impact of these facilities. The provosts report that since these parks have opened university research output (publications and patents) andextramural research have increased. The university’s ability to hire eminent scholars and place doctoral students has remained about the same. It also appears as science parks have resulted in the university curriculum has become more applied. 
Unfortunately, there has been no systematic comparison of the research productivity of firms located on U.S. university research park firms and comparable nonpark firms. The only authors conduct such an analysis were Siegel, Westhead, and Wright (2003), who constructed a longitudinal dataset containing information on the R\&D inputs and outputs of firms located on and off university research parks in the United Kingdom. The authors estimated an R\&D production function and concluded that research park firms are more efficient than non-research park firms in research, in terms of generating new products and patents.

However, there are some U.S. findings with respect to employment growth, which many observers believe is the best measure of park success. Link and Link (2003) report that the employment growth of university research parks is greater the closer the park is to the university; is greater if the park is not operated/managed by the university; is the same whether the park's university is state or private; and is less if there is an incubatory on the park.

\section{Modeling the Decision to Locate on a University Research Park}

We model the decision for a firm to join a university research park based on the economic theory of clubs. That is, we conceptualize membership in the park in terms of an invitation from the 'club' to join the park. ${ }^{1}$ Based on this framework, we can determine the optimal size of a park, and then identify the factors that can induce a change in the optimal size of a park.

The model is described as follows: Consider a university research park that acts as a private organization so that membership in the research park is the result of mutual 
agreement between the existing park tenants including the university - 'the club' - and a potential new member firm. Among the population of firms that are interested in joining the park, let each be characterized by the quality of its R\&D, $q$. Then, the population of such firms can be characterized by the distribution of $q, f(\mathbf{q})$.

The decision to admit a new firm, the $\mathrm{j}^{\text {th }}$ firm (discussed in the following section), into the park depends on the effect of that firm on the well being of the firms already in the park. For simplicity, we assume that there is some "representative" firm already in the park so that the relevant decision rule is whether the prospective member increases the well being of the "representative" member. ${ }^{2}$

For the "representative" firm, hereafter the $i^{\text {th }}$ firm, the value of belonging to the park is the opportunity to engage in synergistic activities that can be used to increase its well being, defined to be profits in the output markets in which it participates. Assume that the $i^{\text {th }}$ firm's potential to engage in synergistic activities is linked to its ability to assimilate new knowledge, that is, to its absorptive capacity, $A$. Assume also that $\mathrm{i}^{\text {th }}$ firm's absorptive capacity is a positive function of the quality of its R\&D, $q_{i}$. Hence:

(1) $\quad A=A\left(q_{i}\right)$

\footnotetext{
${ }^{1}$ This methodology parallels that of Hall, Link, and Scott (2003) to analyze whether a research joint venture invited a university to join as a research member. See also, Leyden and Link (1999) for a similar analysis.

${ }^{2}$ If the decision is made by a simple majority vote of existing firms, the representative firm will be the one with the median view. If the decision is made by a director based on some composite expectation of the effect on members, the representative firm may be some "average firm" (perhaps fictitious).
} 
Assume also that the actual level of its synergistic activities, $S_{i}$, depends not only on the number of other firms in the park and the quality of their $\mathrm{R} \& \mathrm{D},{ }^{3}$ but also on the order in which potential firms are invited to join the park (Sandler and Tschirhart 1980). ${ }^{4}$ Then, the level of synergy of the $\mathrm{i}^{\text {th }}$ firm is a positive, though convex, function of the number of firms, $N$, in the park:

$$
S_{i}=S\left(q_{i}, N \mid f(\mathbf{q})\right) \leq A\left(q_{i}\right)
$$

such that, as shown in Figure 1:

$$
\frac{\partial S\left(q_{i}, N \mid f(\mathbf{q})\right)}{\partial N}>0
$$

(5) $\quad \lim _{N \rightarrow \infty} S\left(q_{i}, N \mid f(\mathbf{q})\right)=A\left(q_{i}\right)$

The $\mathrm{i}^{\text {th }}$ firm engages in synergistic activity to generate profits $\Pi_{i}$ in its output markets.

Assume that such profits increase at a diminishing rate with the level of synergistic activity, $S_{i}$. Thus:

\footnotetext{
${ }^{3}$ The ability to engage in synergistic activities depends both on the quality of R\&D of the firms with which the $\mathrm{i}^{\text {th }}$ firm interacts and on the quality of the firm's own R\&D.
} 
(6) $\quad \Pi_{i}=\Pi\left(S_{i}\right)$

such that, as shown in Figure 2:

(7) $\quad \frac{d \Pi_{i}\left(S_{i}\right)}{d S_{i}}>0$

(8) $\frac{d^{2} \Pi_{i}\left(S_{i}\right)}{d S_{i}^{2}}<0$

Given equation (2):

(9) $\quad \Pi_{i}=\Pi\left(S_{i}\right)=\Pi\left(S\left(q_{i}, N \mid f(\mathbf{q})\right)\right)$

such that, as shown in Figure 3:

(10) $\frac{\partial \Pi_{i}}{\partial N}=\frac{d \Pi_{i}}{d S_{i}} \frac{\partial S_{i}}{\partial N}>0$

(11) $\frac{\partial^{2} \Pi_{i}}{\partial N^{2}}=\frac{d^{2} \Pi_{i}}{d S_{i}^{2}}\left(\frac{\partial S_{i}}{\partial N}\right)^{2}+\frac{d \Pi_{i}}{d S_{i}} \frac{\partial^{2} S_{i}}{\partial N^{2}}<0$

There are, of course, costs associated with belonging to a university research park.

Assume that the cost to the $\mathrm{i}^{\text {th }}$ firm from belonging to the park consists of a fixed

\footnotetext{
${ }^{4}$ In other words, the park will always admit the highest quality firm, among all interested firms, first.
} 
component and a marginal component. The fixed component is the $i^{\text {th }}$ firm's proportional share of total park overhead, which includes such factors as the installation and maintenance of basic infrastructure and park administration. The marginal component, which consists of advertising and marketing, physical maintenance of the park, and the cost of joint park activities, is assumed to increase at an accelerating rate with the number of firms in the park.

Thus, the $i^{\text {th }}$ firm's cost function can be written as:

$$
C_{i}=C_{0}+C_{1} N^{2}
$$

and illustrated in Figure 4. The marginal cost to the $\mathrm{i}^{\text {th }}$ firm of from admitting a new firm into the park is therefore:

$$
\frac{d C_{i}}{d N}=2 c_{1} N
$$

and it is illustrated in Figure 5.

Whether the $\mathrm{i}^{\text {th }}$ firm is better off as a result of a new firm joining the park, and hence, whether the new firm is invited to join the park, depends on the size of the marginal profits to the $\mathrm{i}^{\text {th }}$ firm, $\frac{\partial \Pi_{i}}{\partial N}$, with the new firm, compared to the marginal cost to the $\mathrm{i}^{\text {th }}$ firm, $\frac{d C_{i}}{d N}$, with the new firm. Thus, the decision rule is: 
(14) Admit the new firm iff $\frac{\partial \Pi_{i}}{\partial N} \geq \frac{d C_{i}}{d N}$.

Thus, the equilibrium number of firms in the park will be that number of firms, $N^{*}$, that solves the $\mathrm{i}^{\text {th }}$ firm's objective function:

$$
\max _{N} \Pi\left[S\left(q_{i}, N \mid f(\mathbf{q})\right)\right]-C_{i}(N)
$$

and this solution will be characterized by the first-order condition:

(16) $\frac{d \Pi_{i}}{d S_{i}} \frac{\partial S_{i}}{\partial N}=\frac{d C_{i}}{d N}$

Figure 6 provides the graphical representation of this problem and its solution.

\section{Empirical Analysis}

A key empirical implication of the theoretical model is that firm conducting higher quality research are more likely to locate on a university research park. To test this hypothesis, we identified the population of publicly-traded firms who reported nonzero R\&D expenditures, using the Compustat file. We then determined whether these firms had a research facility located in one of the 81 operating U.S. university research parks as of 2002 - the year of the most recent data on the population of U.S. university research parks (Link and Scott 2006). Our primary resource for mapping each Compustat 
firm to a particular park was the park's directory of tenants. A secondary resource was Internet information regarding each company.

The relative quality of a firm's R\&D is defined in two ways. The first proxy is the level of R\&D expenditure. An alternative definition is the extent to which each firm is diversified in the output market. We conjecture that $R \& D$ expenditure is an indicator of the company's potential to generate research spillovers to other firms on the park and for the creation of a synergistic environment. The extent to which each firm is diversified in the output market also proxies the probability of spillover and synergistic benefits from innovative investments to other park firms. ${ }^{5}$ Firm diversification is calculated from information in the Register of Corporations. We use two alternative measures of diversification: $F D$-the number of 4-digit industrial categories in which each firm reports sales and WFD-the number of 4-digit industrial categories within each firm's major 2digit industry in which each firm reports sales. ${ }^{6}$

The two equations we estimate are:

$$
\begin{aligned}
& \text { Prob in a park }=\mathrm{f}(R D, F D, M A N U F) \\
& \text { Prob in a park }=\mathrm{f}(R D, W F D, M A N U F)
\end{aligned}
$$

\footnotetext{
${ }^{5}$ Not only does this argument follow from our model, it follows from the rich literature about diversification and R\&D activity. See Nelson (1959), Link and Long (1981), Scott and Pascoe (1987), and Link and Scott (2002).

${ }^{6} \mathrm{FD}$ is always greater than or equal to WFD.
} 
where the first two independent variables are defined above and where MANUF if a dummy variable equal to 1 if the firm's primary industry is manufacturing, and 0 otherwise. $^{7}$

Descriptive statistics for the variables included in the regression analysis are presented in Table 1. These figures reveal that $3.1 \%$ of the 2,435 Compustat firms reporting $R \& D$ expenditures in 2002 were located on a university research park. Not surprisingly, firms that conduct $R \& D$ are likely to be engaged in manufacturing activities.

Table 2 presents Probit regression estimates of the marginal effects of each of the independent variables. Note that in each variant of the model, the marginal effect of R\&D expenditures is positive and significantly related to the probability that a firm will locate in a research park. There is evidence that the $\mathrm{R} \& \mathrm{D}$ effect is non-linear, being positive to a level of R\&D of nearly $\$ 4$ billion. However, fewer than one-half of one percent of American firms allocate that much money to R\&D. Thus, over what we consider the relevant range of $R \& D$ expenditures, our theoretical prediction holds.

For both measures of diversification, the marginal effect is positive and significantly related to the probability that a firm will locate in a research park. This finding also corresponds to our theoretical prediction. Note that the above two conclusions hold whether a prospective firm is in the manufacturing sector or the service sector.

\section{Conclusions}

\footnotetext{
${ }^{7}$ Gallaher, Link, and Petrusa (forthcoming) show that the nature of R\&D varies significantly among firm in the manufacturing compared to those in the non-manufacturing sector.
} 
The empirical analysis appears to confirm the predictions from our theoretical model. Our findings also provide some strategic guidance to universities that are either recruiting firms to newly-established parks or to planned parks. As a benchmark, universities with a limited 'recruiting budget' should focus on those firms that are relatively more R\&D active and that are more highly diversified. Note from Table 1 that only about 3 percent of the population of public R\&D-active firms has a research facility located in a university research park. Thus, the size of the potential population of firms to recruit to locate in a park is large.

From the firm's perspective the decision to locate on a university research park is dependent on its ability to realize innovation externalities from other members in the park including the university. As such, decision makers should consider the scale, scope, and diversification of park members as well as the potential for new members before committing to a park location. As noted above, of the 39 planned parks as of 2002, 40 percent plan to focus specifically on biotechnology. If this is indicative of a trend towards the adoption of a specific technology focus, then prospective university research park tenants should consider both the current and future state of research synergies. 


\section{Figure 1}

The Actual and Potential Level of Synergistic Activities by the $i^{\text {th }}$ Firm in the University Research Park

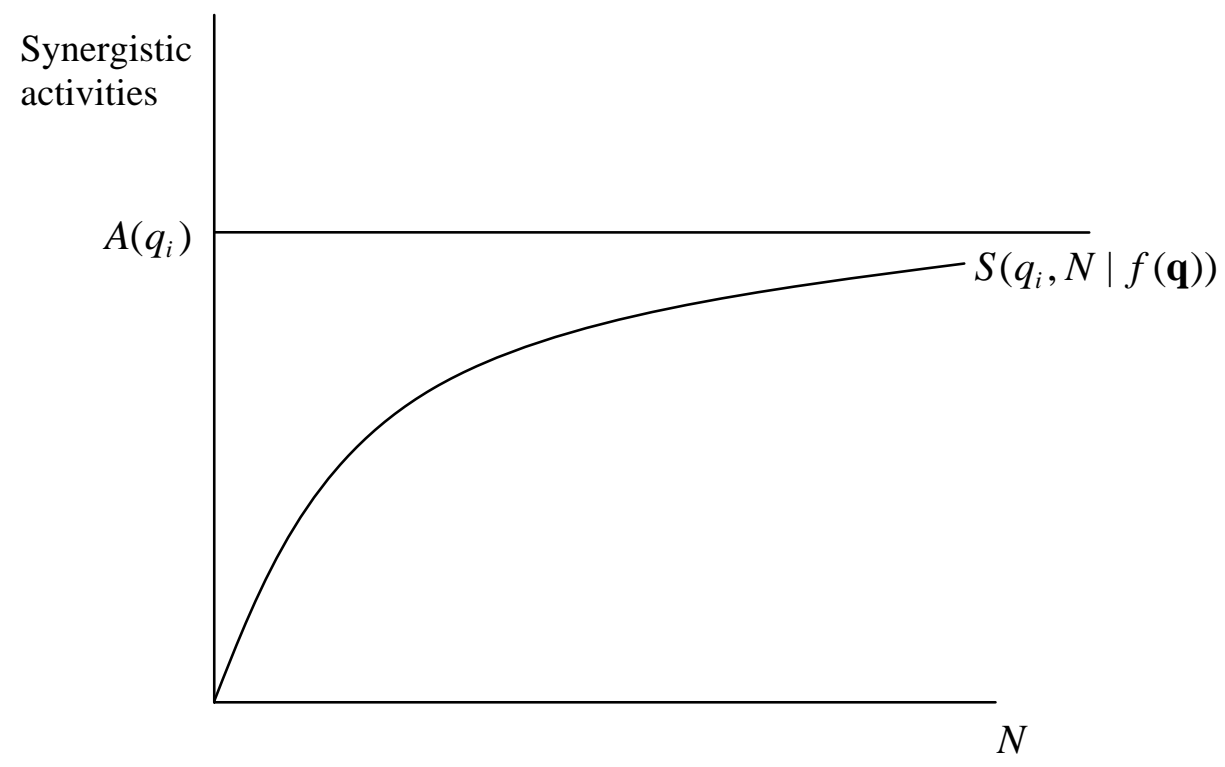


Figure 2

The $i^{\text {th }}$ Firm's Total Profits as a Function of University Research Park Size

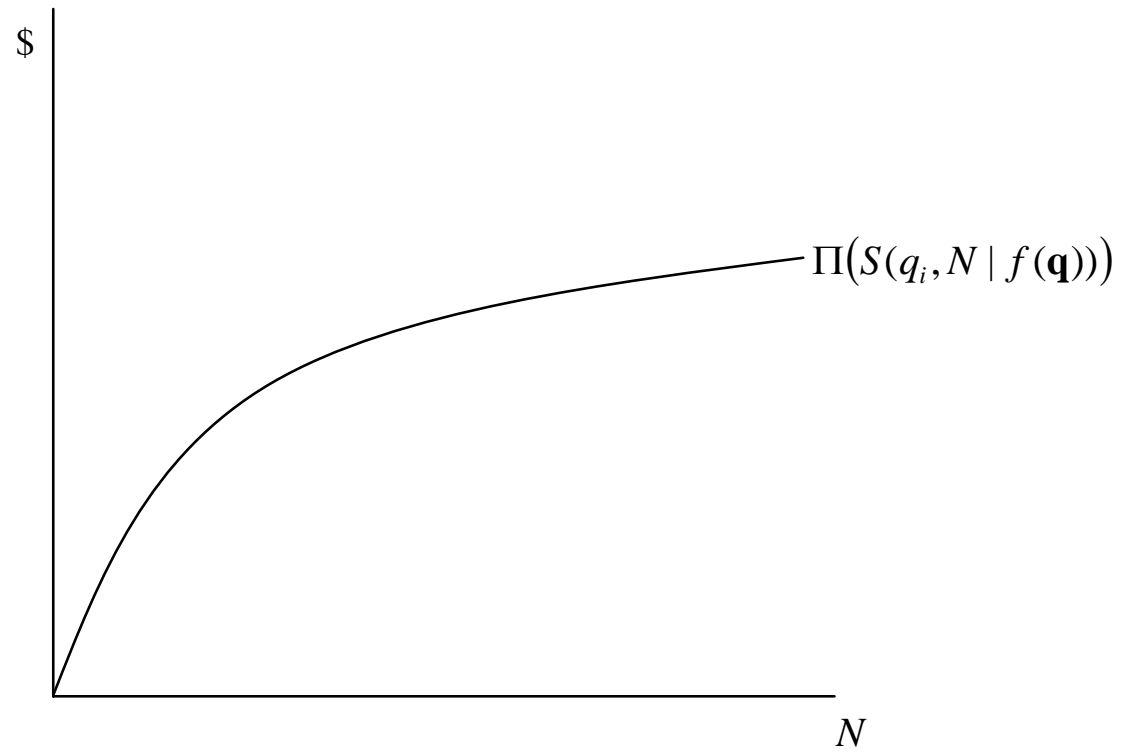


Figure 3

The $i^{\text {th }}$ Firm's Marginal Profits as a Function of University Research Park Size

$\$$

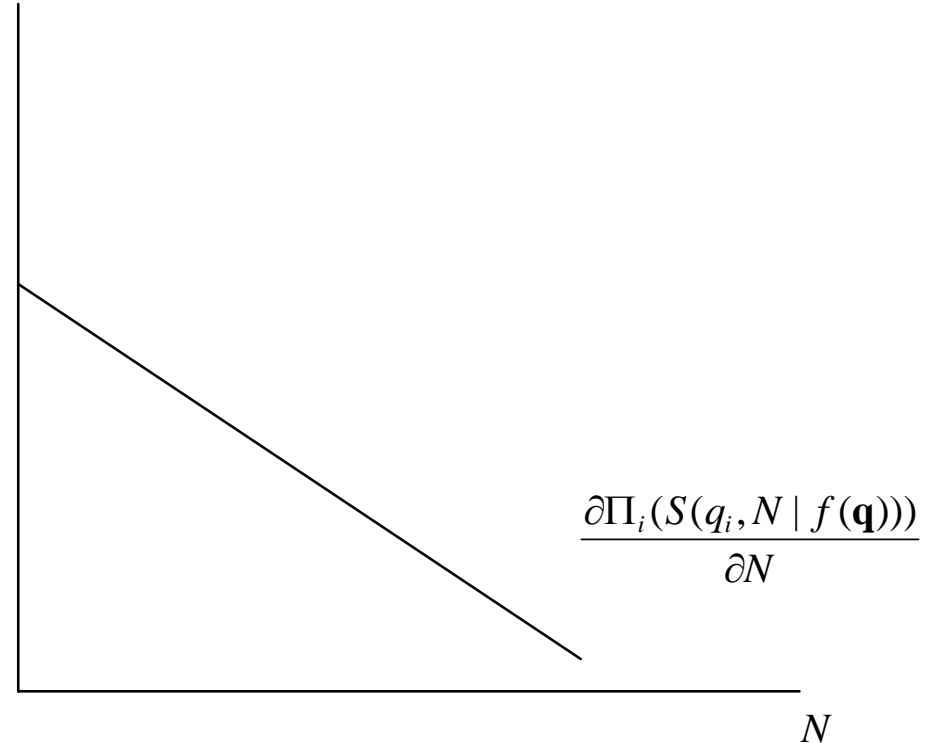


Figure 4

Total Cost to the ith Firm from its University Research Park Membership

$\$$

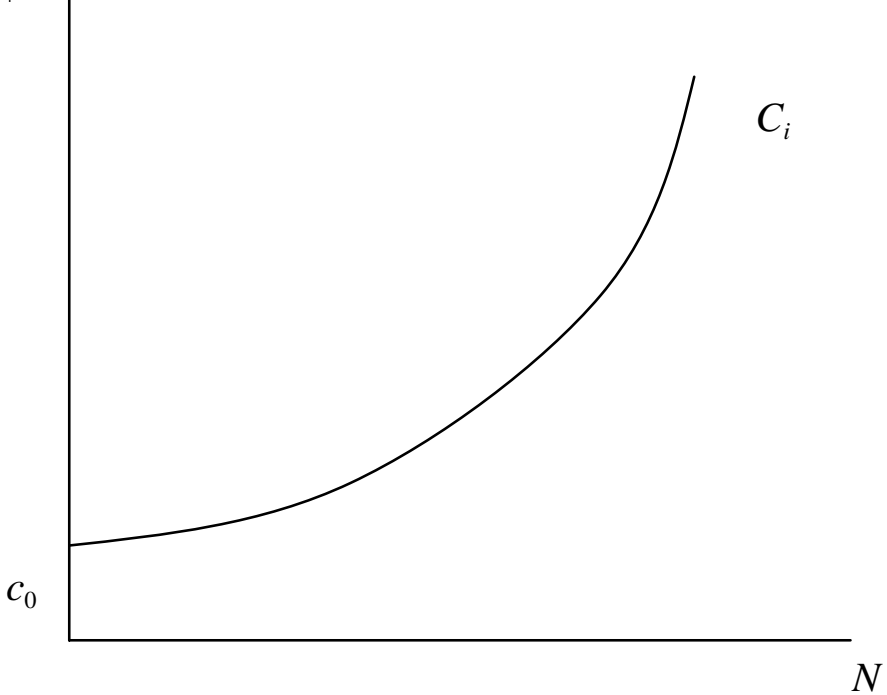


Figure 5

Cost to the $\mathrm{i}^{\text {th }}$ Firm from Membership in the University Research Park

$\$$

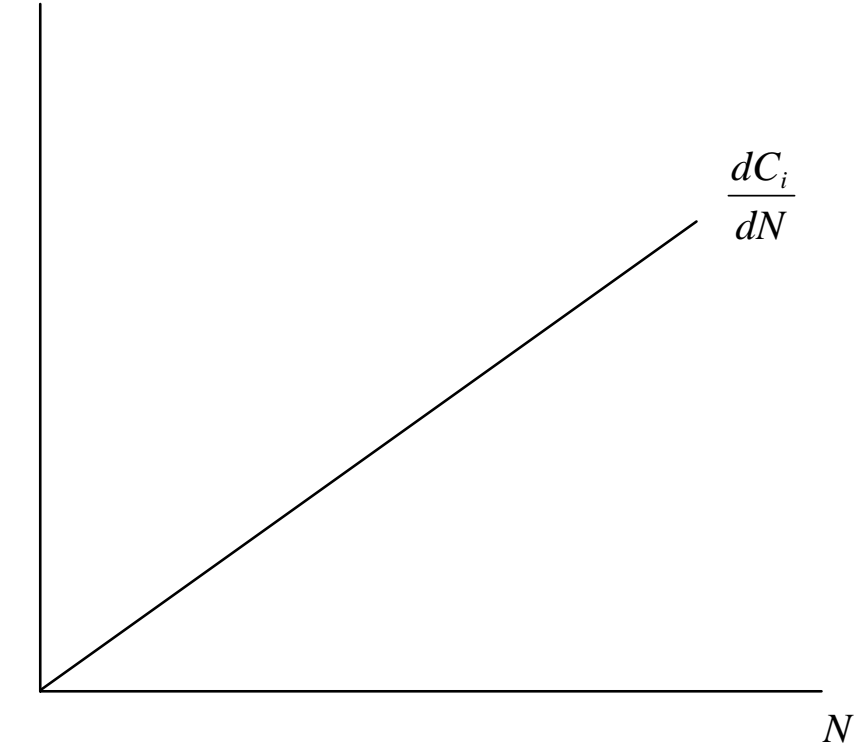


Figure 6

The Optimal Number of Firms in a University Research Park

$\$$

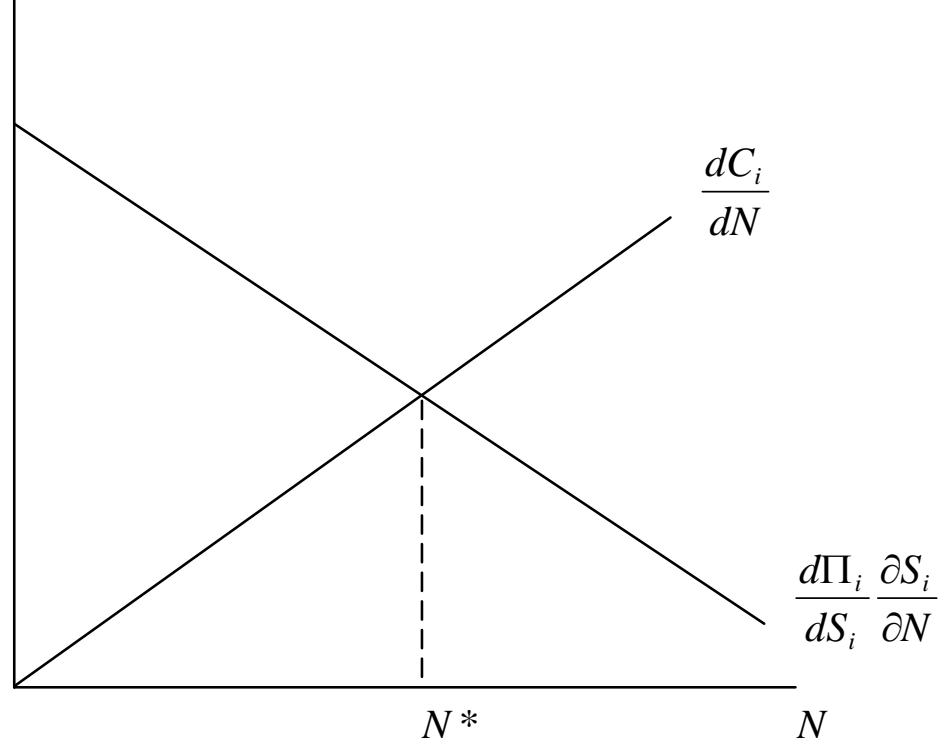


Table 1

Descriptive Statistics for Variables Included in the Regression Analysis $(n=2,142)$

\begin{tabular}{|l|c|c|}
\hline Variable & Mean & Standard Deviation \\
\hline InPark & .031 & \\
\hline RD $($ \$mil $)$ & 117.9 & \\
\hline FD & 2.42 & \\
\hline WFD & 1.55 & \\
\hline Manuf & 0.73 & \\
\hline
\end{tabular}

Note: The sample of firms was reduced from the 2,435 Compustat firms because many were not listed in the Register of Corporations, from which the diversification information was obtained. 
Table 2

Marginal Effects of Variables in Equation (17) from Probit Estimates (standard errors in parentheses, $n=2142$ )

\begin{tabular}{|c|c|c|c|c|}
\hline Variable & (1) & (2) & (3) & (4) \\
\hline$R D$ & $\begin{array}{c}.000046 \\
(.000007)^{*}\end{array}$ & $\begin{array}{c}.00016 \\
(.000018)^{*}\end{array}$ & $\begin{array}{c}.00004 \\
(.000007)^{*}\end{array}$ & $\begin{array}{c}.00015 \\
(.000018)^{*}\end{array}$ \\
\hline$R D^{2}$ & -- & $\begin{array}{c}-2.12 \text { E-8 } \\
(2.99 \text { E-9)* }\end{array}$ & -- & $\begin{array}{c}-1.95 \text { E-8 } \\
(2.98 \text { E-9)* }\end{array}$ \\
\hline$F D$ & $\begin{array}{c}.0037 \\
(.0012)^{*}\end{array}$ & $\begin{array}{c}.0019 \\
(* .0012)^{* * *}\end{array}$ & -- & -- \\
\hline WFD & -- & -- & $\begin{array}{c}.016 \\
(.0028)^{*}\end{array}$ & $\begin{array}{c}.012 \\
(.0028)^{*}\end{array}$ \\
\hline MANUF & $\begin{array}{l}-.0050 \\
(.0083)\end{array}$ & $\begin{array}{l}-0.0077 \\
(.0082)\end{array}$ & $\begin{array}{l}-0.0068 \\
(.0082)\end{array}$ & $\begin{array}{l}-.0095 \\
(.0082)\end{array}$ \\
\hline Log Likelihood & -275.21 & -264.84 & -268.69 & -260.29 \\
\hline
\end{tabular}




\section{References}

Audretsch, David B. “The Prospects for a Technology Park at Ames: A New Economic Model for Industry-Government Partnerships?,” in A Review of the New Initiatives at the NASA Ames Research Center, edited by C. Wessner, National Academy Press: Washington, DC, 2001.

Gallaher, Michael P., Albert N. Link, and Jeffrey A. Petrusa. Innovation in the U.S. Service Sector, Routledge, UK, forthcoming.

Hall, Bronwyn H., Albert N. Link, and John T. Scott. "Universities as Research Partners,” Review of Economics and Statistics, 85: 485-491, 2003.

Leyden, Dennis P. and Albert N. Link. "Federal Laboratories as Research Partners," International Journal of Industrial Organization, 17: 557-574, 1999.

Link, Albert N. A Generosity of Spirit: The Early History of the Research Triangle Park, University of North Carolina Press for the Research Triangle Park Foundation: Research Triangle Park, NC, 1995.

Link, Albert N. From Seed to Harvest: The History of the Growth of the Research Triangle Park, University of North Carolina Press for the Research Triangle Park Foundation: Research Triangle Park, NC, 2002.

Link, Albert N. "What We Know (and Don't Know) about U.S. University Research Parks,” seminar presentation at the National Science Foundation, October 19, 2004.

Link, Albert N. and Kevin R. Link. “On the Growth of U.S. Science Parks,” Journal of Technology Transfer, 28: 81-85, 2003.

Link, Albert N. and James E. Long. “The Simple Economics of Basic Scientific Research: A Test of Nelson's Diversification Hypothesis,” Journal of Industrial Economics, 30: 105-109, 1981.

Link, Albert N. and John T. Scott. "Explaining Observed Licensing Agreements: Toward a Broader Understanding of Technology Flows, Economics of Innovation and New Technology, 11: 221-231, 2002.

Link, Albert N. and John T. Scott. “The Growth of Research Triangle Park,” Small Business Economics, 20: 167-175, 2003a.

Link, Albert N. and John T. Scott. "U.S. Science Parks: The Diffusion of an Innovation and Its Effects on the Academic Mission of Universities," International Journal of Industrial Organization, 21: 1323-1356, 2003b. 
Link, Albert N. and John T. Scott. "U.S. University Research Parks,” Journal of Productivity Analysis, 25: 43-55, 2006.

Nelson, Richard R. "The Simple Economics of Basic Scientific Research,” Journal of Political Economy, 67: 297-306, 1959.

Phan, Phillip, Donald S. Siegel, and Mike Wright. "Science Parks and Incubators: Observations, Synthesis and Future Research,” Journal of Business Venturing, 20(2): 165-182, 2005.

Sandler, Todd, and John T. Tschirhart. The Economic Theory of Clubs: An Evaluation Survey, Journal of Economic Literature 18: 1481-1521, 1980.

Scott, John T. and George Pascoe. "Purposive Diversification of R\&D in Manufacturing,” Journal of Industrial Economics, 36: 193-205, 1987.

Siegel, Donald S., Paul Westhead, and Mike Wright. "Assessing the Impact of University Science Parks on Research Productivity: Exploring Firm-Level Evidence from the United Kingdom,” International Journal of Industrial Organization, 21: 1357-1369, 2003.

Siegel, Donald S., Paul Westhead, and Mike Wright. "Science Parks and the Performance of New Technology-Based Firms: A Review of Recent U.K. Evidence and An Agenda for Future Research,” Small Business Economics, 20: 177-184, 2003. 